\title{
消費者が緑茶に求める嗜好性にあった品種のブレンド
}

\author{
埼玉県茶業研究所* \\ 佐々木功二 ${ }^{\dagger}$
}

（2018年 6 月14日受理）

\section{Blending the Teas Produced by the Five Cultivars}

\author{
Koji Sasaki \\ Saitama Tea Research Institute
}

Key Words : preference, cultivar, blending, consumers

キーワード：嗜好, 品種, ブレンド, 消費者

\section{1 はじめに}

緑茶は嗜好品と言われるように, 飲用する消費者の経 験や生活地域, さらには同一人物であっても飲用場面や 体調など様々な要因によって嗜好は変化する。このよう に緑茶は嗜好の多面性があるにもかかわらず，実際に緑 茶を販売している場面をみると, 緑茶を購入するための 選択肢は煎茶やほうじ茶といった茶種を除き, その多く は価格に依存している。

緑茶に限らず多くの食品では, 価格の決定要素は生産 者や流通者の品質評価である。ところが緑茶の嗜好は 様々な条件により変化するため, 消費者の嗜好と茶の生 産者や流通者（以下, 「茶業者」とする）の品質評価と は必ずしも一致しない。それにもかかわらず，価格以外 の品質情報は消費者にはほとんど伝えられないため, 消 費者は嗜好と合致した緑茶の入手が難しい。このような 茶業者が意図する品質情報を消費者が入手できないこと を, 糀谷・合崎 ${ }^{1)}$ は「情報非対称性が大きい製品」と 表現している。
著者は緑茶の消費を減少させている要因の一つが, 緑 茶が情報の非対称性が大きい製品のために，消費者が持 つ嗜好にあった緑茶を購入できなかったり, 緑茶の価格 と消費者の嗜好の乘離により相応の価值を見いだせなか ったりする不満にあると考えてきた。

一方, 緑茶の選択肢を品質評価以外に求める動きもわ ずかながら出てきている。例えば, 緑茶カフェと呼ばれ る日本茶を扱う喫茶店のホームページを見ると, 価格だ けではなく, 品種別, 産地別のメニューがある。メニュ 一には品種や産地の香味の特徵などが紹介されており, 消費者は価格の他に品種などの特徴を見ながら自分の 好みと合致する緑茶を選択できる。前掲の糀谷ら ${ }^{1)}$ は, 全国的には知名度が低い三重県産の「伊勢茶」も, 産地情 報やかぶせ茶といった煎茶と異なる製品情報を掲載する ことで選好強度が高まると報告している。また植松ら ${ }^{2)}$ も, 香味の品質表示によって購入意欲が高まったり, 価 格感度が上がる傾向にあったりするなどの効果があった ことを報告している。これらの取り組みは, 茶業者の品 質評価である価格以外の情報を消費者に提示すること で，消費者の緑茶の選択を助けている例である。 
また価格以外の品質情報を広げる視点から, 消費者と 接点が多い日本茶インストラクターなどからは, 消費者 の嗜好と茶の品種関係に着目した検証 ${ }^{3)}$ や, 地域によ る嗜好の違いを検証した報告も出てきている ${ }^{4)}$ 。その他 に, 緑茶ハンドブッグには, 日本茶インストラクター による品種の試飲アンケート調查の記載が始まっている。

このような, 品種や産地情報, 製品の特長の提示は, 情報の非対称性を小さくする手段としては有効である。 しかし，これらの品種や産地情報，製品の特徵などの情 報は，あくまでも消費者が意識的・無意識的にもつ緑茶 に対する嗜好の属性と合致するかを, 消費者が確認 · 選択する手段でしかない。そのため, 提示された情報が 消費者の求める嗜好と合致しなければ販売に結び付かな い。また香味などの情報は表示者の主観に依存するため, 消費者の嗜好の感受性と必ずしも一致しないことが予想 される。

さらに緑茶の嗜好は, 個人ごとの経験や生活環境など により大きく変化する。前掲の糀谷ら ${ }^{1)}$ は「調查結果 の限界」として,「緑茶飲用頻度が地域間で差が見られ たものの, 他の個人属性については有意差が確認されな かった」としている。そして,「どのような消費者を夕 ーゲットとして販売戦略を立てるか具体的に検証するた めには, 回答者の個人特性まで踏み込んだ検証が必要と なる。としている。つまり緑茶の嗜好は個人特性の一 つであり，そのため一般的な喍好調査に用いられている 「性別」「年齢」などの個人属性では，嗜好を正確に把握 することは難しい。そこで, 個人特性の一つといえる消 費者が緑茶に求める嗜好を具体的に把握するため, 味や 香気などの特徴（品質）ごとに嗜好を確認する，嗜好属 性を新たに設定する必要がある。

ところで，様々な新品種や珍しい品種などを試飲する と, 品種単独では個性が強いものが多い。しかし, 個性 の強い品種を ‘やぶきた’ と組み合わせると, 強い個性 が緩和されて好ましい香味になることが多い。また, ‘や ぶきた，さやまか抢り’などの市場評価が固まっている 品種でも, 合組の比率によって香味が大きく変化する。 これらの点を考慮すると, 品種などの合組（以下，「ブ レンド」とする）は，多様化する消費者の嗜好に対応で きる可能性がある。

しかしながらブレンドは, 茶の流通を担う限られた茶 業者のほぼ独断場である。しかも, 緑茶のブレンドは品 質の多様性のために行われているわけではない。前掲の 川口 ${ }^{3)}$ は，現在の緑茶のブレンド目的は，できるだけ
製品の品質を画一化させてロット数を減らし, 流通販売 の効率化・コスト低減を図るために行われていると指摘 している。

またブレンドの技術面から，渕之上 ${ }^{5)}$ は緑茶のブレン ドについて「どの棒とどの技茶をどれくらいの割合で 混ぜたらよいかは、茶師の長年の経験の蓄積と勘による もので、一朝一夕にできるものではない。」と述べている。 このように緑茶のブレンドは, 一部の茶業者が築き上 げてきた「経験と勘」に依存する技術である。そのため, 目的とする緑茶の香味をブレンドによって引き出すこと は, 科学的な再現性や客観的な表現などが困難であり研 究対象になりにくい。このような理由により, ブレンド による香味などの品質の変化に関する知見の報告や, 品 種などのブレンドによって消費者の嗜好に対応した緑茶 を創りあげたという報告はほとんど見当たらない。

そこで, 消費者の多様な嗜好に対応するための手段と して, 品種のブレンドを利用する方法を実施することに した。その前提として, (1)情報の非対称性の解消のため, 茶の提供者から消費者に対して品種の香味などの情報提 示，(2)消費者からの嗜好情報をできるだけ具体的に得る ため, 消費者との対面方式で嗜好の聞き取り，(3)(2によ って得られた情報をもとに品種の特徴を考慮したブレン ド茶を呈茶し, 喏好が合致の有無を確認し、嗜好が一致 しない場合再度ブレンドを行うといった手法での調査を 実施した。特に，(2)の消費者からの嗜好情報については， 消費者が判断しやすいと思われる緑茶の味や香りなどの 特徵（品質）を嗜好属性として設定し, その有效性につ いても検討を行った。その結果, 消費者の緑茶に対する 嘫好の多椂性など一定の知見を得たので報告する。

\section{2 方 法}

\section{1 イベントでの嗜好調査}

最初は, 2012年 5 月に埼玉県茶業研究所 (以下, 「茶研」 とする)で実施している消費者向けのイベント(以下,「イ ベント」とする)の企画として実施した。企画の名称は, 消費者の嗜好や希望に応じて個々に品種をオーダーメイ ドでブレンドすることから「オーダー銘茶会」(以下，「銘 茶会」とする) とした。

その結果, 銘茶会の参加者の嗜好に合った品種のブレ ンド割合は, 参加者ごとに異なっただけではなく, 参加 者の嗜好に合致したブレンドは“やぶきた’をべースに ブレンドされていると思われる市販茶とも差があった。 
しかしながら2012年の銘茶会においては，提供した品 種の特徵や品種のブレンド比率の記録を残さなかった。 そのため, 消費者が望むブレンドの姿を漠然としかとら えることができなかった。そこで，2013年以降に実施し た銘茶会では，参加者の嗜好を聞き取り、それに基づい てブレンドした品種の比率などについてできうる限り記 録を行った。その記録をもとに, 品種ブレンドから消費 者の嗜好や煎茶に対する意識について検討を試みた。

\section{2 銘茶会の会場の様子}

会場となる部屋の都合により若干異なるが, 参加者が ブレンドする様子を見られるように机などを配置した。

\section{3 オーダー銘茶会の参加人数}

2016年まではブレンドや呈茶作業を 1 人で行うため, 参加人数は 1 回 3 グループまでとした。2017年は補助員 4 人を配置できたので, 参加人数は 1 回 4 グループとし, 1 グループ 4 人までとした。

銘茶会への参加申し込みは、その年にイベントに来場 した人が当日申込制とし，申込の際に，4 人以内を 1 グ ループとして申し込みを打願いした。なお，参加者は抽 選により無作為に決めため、グループの人数は 1 人〜 4
人に分かれ， 2 人以上の場合、夫婦、親子，友人などグ ループ内の関係もさまざまであった。また，年ごとに参 加者はすべて異なった。

\section{4 供試品種}

茶研及び埼玉県内の製茶農家で製造した，市販茶 1000 円 $/ 100 \mathrm{~g}$ 相当の深蒸し（蒸熱時間70 100秒）の仕上茶 で, 単一品種, 5 品種を供試した（表 1 )。 品種の選定は, 埼玉県で栽培面積が多い品種のほか, 栽培面積は少ないが味や香気に特徵がある品種, 埼玉県 においてこれから普及を図りたい品種を基準に行った。 オーダーメニューは消費者に対する品種のアピールも兼 ね, 提供品種と同じ品種を, 同日に実施しているイベン トでも単品販売を行った。

供試品種は著者が事前に官能審査を行い，後述する参 加者への嗜好調査の項目に基づいた嗜好属性を特定し, 年により異なる品種の香味などの特徴はもとより, 同一 品種であっても年ごとの作柄により品種の特徵に逸脱が ないかを把握した。また, 代表的な品種のブレンドによ るシミュレーションを行った（表 2$)$ 。さらに供試品種 の特徴の説明文を「オーダーメニュー」として参加者に 提示した。

表 1 実施年別の供試品種

\begin{tabular}{|l|llll|}
\hline 実施年 & \multicolumn{3}{|c|}{ 供試品種 } \\
\hline 2013年 & やぶきた & さやまかおり & ふくみどり & ほくめい \\
\hline 2014年 & やぶきた & さやまかおり & ふくみどり & ほくめいが \\
\hline 2016年 & やぶきた & さやまかおり & むさしかおり & ほくめい \\
\hline 2017年 & やぶきた & さやまかおり & ふくみどり & ほくめい \\
\hline
\end{tabular}

\section{表 2 供試品種の特徵とブレンドに際する考え方}

\begin{tabular}{|c|c|c|}
\hline 供試品種 & 巣好属性 & 急須で浸出した香味の特徵・ブレンドの考え方 \\
\hline やぶきた & さっぱり味 & $\begin{array}{l}\text { こくのあるうま味は少ないが, そう快なさっぱりした味。香気はわずかに新鮮香。香味に特徵のある品種 } \\
\text { とブレンドすると, ブレンド相手の品種の特徵をうまく引き出す。 }\end{array}$ \\
\hline さやま & $\begin{array}{l}\text { さっぱり味 } \\
\text { 苦渋味 }\end{array}$ & $\begin{array}{l}\text { 苦渋味が強くこくのあるうま味は少ないが, さっぱりした味。香気はわずかに新鮮香。苦渋味を引き出し } \\
\text { たり, 苦渋味を強くしたりする希望があった場合のブレンドに利用。 } \\
\end{array}$ \\
\hline ふくみ & こく味 & $\begin{array}{l}\text { こくのあるうま味が強い。香気はややむれ臭や青臭が感じられ，そう快さがない。やぶきた などのさっ } \\
\text { ぱり味の品種と組み合わせると, バランスのとれたこくを引き出すことができる。 }\end{array}$ \\
\hline ほく & $\begin{array}{l}\text { こく味 } \\
\text { 強い香気 }\end{array}$ & $\begin{array}{l}\text { こくのあるうま味がある。香気はそう快な萎调香がある。やぶきたやささやまかおり とブレンドするとそ } \\
\text { う快な香気がょり強くなり，甘い香気の品種とブレンドすると甘い香気がょり強くなる。 }\end{array}$ \\
\hline Wx & $\begin{array}{l}\text { こく味 } \\
\text { 強い香気 } \\
\text { 甘い香気 }\end{array}$ & $\begin{array}{l}\text { こくのあるうま味がある。香気は甘い萎调香をしっかりと感じるが, そう快さは少ない。甘い香気や強い } \\
\text { 香気の希望があった場合のブレン゙に利用。 }\end{array}$ \\
\hline むさし & $\begin{array}{l}\text { さっぱり味 } \\
\text { 強い香気 } \\
\text { 甘い香気 }\end{array}$ & $\begin{array}{l}\text { こくのあるうま味は少ないが, さっぱりした味。香気は甘さのある相橘系のような萎调香をしっかりと感 } \\
\text { じる。水色が赤く, 甘い香気や強い香気の希望があった場合のブレン゙に利用。 }\end{array}$ \\
\hline おくl & $\begin{array}{l}\text { こく味 } \\
\text { 強い香気 } \\
\text { 甘い香気 }\end{array}$ & $\begin{array}{l}\text { こくのあるうま味が強い。香気は桜葉様の甘い香気をしっかりと感じる。香気を生かすブレンドの他、苦 } \\
\text { 渋味が少ないので, 苦渋味の強い品種と組み合わせると味がしっかする。 }\end{array}$ \\
\hline こ & $\begin{array}{l}\text { さっぱり味 } \\
\text { 強い香気 } \\
\text { 甘い香気 }\end{array}$ & $\begin{array}{l}\text { こくのあるうま味は少ないが, さっぱりした味。香気は甘い香気がしっかりと感じられる。水色が } \\
\text { く, 水色にこだわりがなく甘い香気の希望があった場合のブレンドに利用。 }\end{array}$ \\
\hline
\end{tabular}

注）嗜好属性は,「図 1 参加者に配布した問診票」の問診項目に基づく品種の特徵区分。 
なお, 茶研内のほ場や埼玉県内の茶農家において栽培 面積は少ない品種については，作柄によりすべての年で 同一品種同等品質のものを揃えることが困難であった。 しかし同一品種が提供できない場合においても，代替品 種は事前の官能審査により品種のブレンドを決めるため に必要な味, 香気, 水色の特徵が可能な限り似た品種を 選定した。

また，拝見盆には供試品種の外観見本の茶葉約 $150 \mathrm{~g}$ を, グループごとに準備し，参加者が茶葉を自由に触っ たり香気などを確認したりできるようにした。

\section{5 銘茶会の流れ}

\section{5.1 参加者の嗜好聴取}

参加者に対して嗜好属性を確認する目的で, 味, 香 気, 水色, 緑茶の飲用に対するこだわりについて問う, 「問診票」と称したアンケートを実施した（図 1 )。また, 問診票の回収と同時に，口頭において補足的に嗜好の聞 き取りを行った。問診票の設問項目は，ブレンドの際に
必要となる品種の特徽や嗜好属性と関連付けができるよ うに, 設問 $1 \sim 4$ を味に関する嗜好要素, 設問 5 〜 香気に関する嗜好要素, 設問 $8 \sim 9$ を水色に関する嗜好 要素, 設問10〜12を茶のこだわりに関する喏好要素とし て挙げた。また設問内容は, 参加者が嗜好について判断 できると思われる要素にした。そのため, 味に関する設 問にくらべて, 香気や水色は消費者に理解・判別できる と思われる要素が少なく, 設問項目数に差が生じた。設 問数の差については，2回目以降のブレンド時に口頭で の聞き取りをすることで補足した。

なお, グループ内の参加者が複数の場合は, そのグル ープ内の参加者で意見を集約, または特定の代表者の嗜 好に統一するように参加者に依頼を行った。

\section{5. 2 品種のブレンドと試飲}

問診票等の嗜好調査結果に基づき, 品種のブレンドを 行った。ブレンドは, 滋味の審査で用いるスプーンに茶 葉 1 杯（約 $3 \mathrm{~g}$ ）を 1 品種, 1 単位としてカルトンにと り, 混合した（図 2 )。2013・2014年は, 1 回のブレン

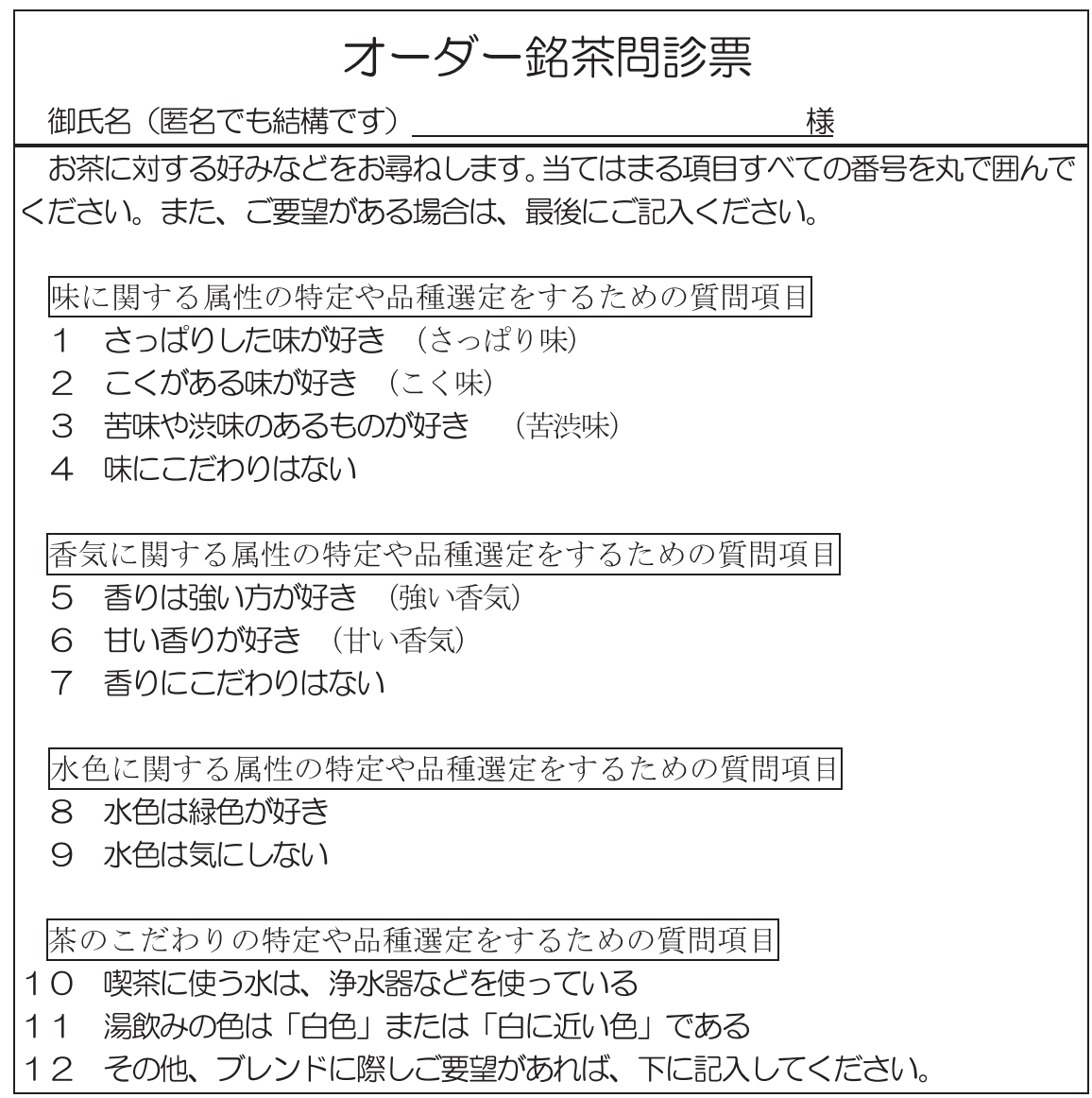

図 1 参加者に配布した問診票（嗜好調査用紙）

注） 1 囲みの部分は，本稿の説明のために追加した記述。銘茶会の参加者には提示していない。

注） 2 （）内は, 「表 2 供試品種の特徵とブレンドに際する考え方」における「墸好属性」の項目。銘茶会の参加者には提示していない。

注） 3 質問項目6の「甘い香り」は，香気が強い品種の中で，特に甘い香気のする品種選択を想定した。 


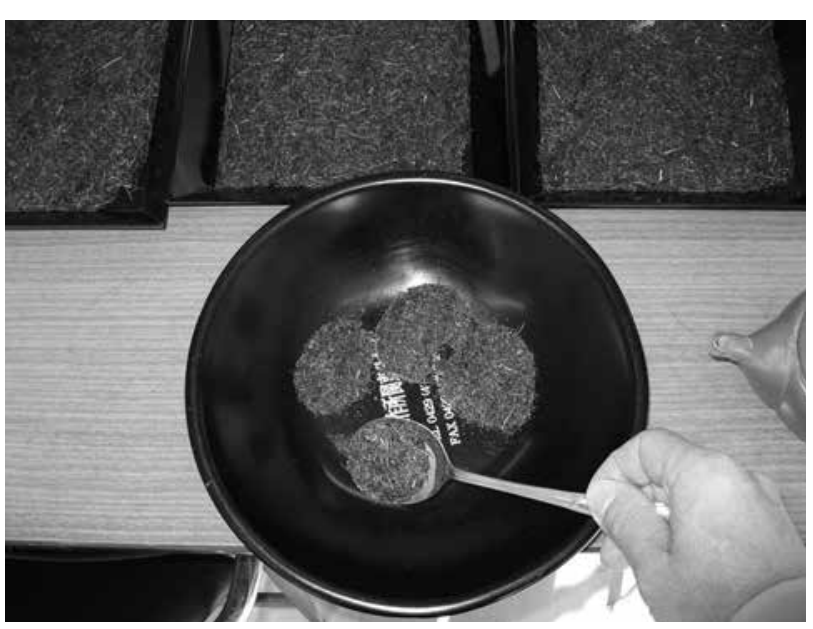

図 25 品種の中から希望に応じてブレンド ( 1 匙約 $3 \mathrm{~g}$ 。最終的に $10 \mathrm{~g}$ 以上になるようにして、混合)

ドを10杯に固定して品種を組み合わせたが，2016・2017 年は杯数を決めずにブレンドを行った。

品種のブレンドにあたっては, あらかじめ官能審査な どによって把握した各品種の特徵や, 著者の事前のブレ ンドシミュレーションにもとづき, 参加者の嗜好調査結 果を嗜好属性と考えてブレンドを行った。以下に, 事前 のブレンドシミュレーションに基づき, 参加者が希望す る香味の特徵が生かされると考えた，初回のブレンドの 方法を記す。ただし，品種の組み合わせにより完全には 当てはまらないこともある。

\section{(1) 味について}

「さっぱり味」が希望の場合, さっぱり味の嘹好属性 を持つ品種のブレンド比率を全体の $50 \%$ 以上になるよう にした。

「こく味」が希望の場合, こく味の嗜好属性を持つ品 種のブレンド比率を全体の $30 \%$ 以上になるようにした。

「こく味」と「さっぱり味」の両方が希望の場合, さ っぱり味よりもこくが強く出るものと考え, こく味の嗜 好属性をもつ品種のブレンド比率を全体の $30 \%$ 以下にな るようにした。

「苦渋味」が希望の場合, 苦渋味の嗜好属性を持つ品 種のブレンド比率を全体の $50 \%$ 程度になるようにした。

\section{(2) 香気について}

「強い香気」が希望の場合，強い香気の嗜好属性を持 つ品種のブレンド比率を全体の $30 \%$ 以上になるようにし た。

強い香気のうち，参加者にも香気の特徵を判断しやす いと思われた「甘い香気」が希望の場合，甘い香気の嗜 好属性を持つ品種のブレンド比率を全体の $30 \%$ 以上にな るようにした。

\section{（3）水色について}

「水色にこだわりがない」場合，香気は強いが水色が やや劣る品種などのブレンドも行った。

(4) 緑茶品質以外のこだわりについて(浄水器の使用, 湯吞の色）

浄水器の使用がない場合, 香気の強い品種の割合を上 述の基準より増やすようにした。また，湯吞が白以外の 回答で，かつ参加者に香気にこだわりがあると判断した 場合は, 水色よりも香気などの特徵を優先したブレンド を行った。

ブレンドした茶の試飲は，参加者が日常の生活におい て急須で淹れることを前提に, 深蒸し煎茶の淹れ方に関 するホームページなど消費者向けの情報をもとに，ブ レンド茶葉約 $3 \mathrm{~g}$ を容量約 $300 \mathrm{~mL}$ 急須にいれ, 温度 約 $60^{\circ} \mathrm{C}$ の湯，約 $200 \mathrm{~mL}$ 急須に注ぎ，30秒浸出とした。 浸出後は, 同じ容量の急須に注ぎかえて各組に呈茶した。 参加者は試飲を行い, 希望の香味や水色になったかを確 認した。

\section{5.3 嗜好の合致の確認，ブレンド比率の記録}

試飲の結果, グループの参加者の嗜好と合致した時点 で，その品種のブレンド比率を記録した。啫好と合致し なかった場合は，嗜好が一致しない内容や香味などの希 望について口頭による聞き取りを行い，再度ブレンド・ 試飲を実施した。

\section{5.4 銘茶会に対する感想の聴取}

銘茶会に対する感想などについて，アンケート形式で 参加者に回答を依頼した。

\section{3 結 果}

\section{1 参加者の嗜好調査とブレンド結果}

2013年から実施した 4 か年の嗜好調査の結果と, 参加 者が最も好ましいとした品種ブレンドおよび品種の特徴 別のブレンド比率を，実施年ごとに示す。

\section{1 . 1 2013年}

問診票による嗜好調査の結果，味は「さっぱり味」を 希望が 1 組,「こく味」を希望が 3 組, 「苦渋味」を希望 が 2 組, 香気は「強い香気」の希望が 2 組,「甘い香気」 が 1 組, 水色が「緑色」希望が 1 組などとなった (表 3 )。 最終的に，参加グループが最も好ましいとした品種比 率のうち，記録をとった 3 組（グループ番号 1 〜 3 ）の 品種比率と, 3 組全体の品種別の平均比率を示した（表 4 )。

次に, 各嗜好属性に応じたブレンド結果を示す (表 5 )。 
表 3 嗜好調査結果（2013年）

\begin{tabular}{|c|c|c|c|c|}
\hline & \multirow{2}{*}{ 問診項目 } & \multicolumn{3}{|c|}{ グループ番号 } \\
\hline & & 1 & 2 & 3 \\
\hline 1 & さっぱり味 & $\mathrm{O}$ & & \\
\hline 2 & こく味 & 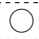 & 5 & \\
\hline 3 & 苦渋味 & & 0 & \\
\hline 4 & 味こだわり無 & 5 & & \\
\hline 5 & 強い香気 & & b & J \\
\hline 6 & 甘い香気 & & & \\
\hline 7 & 香気こだわり無 & & & \\
\hline 8 & 水色緑 & 5 & & \\
\hline 9 & 水色こだわり無 & 0 & & \\
\hline 10 & 浄水器等使用 & 0 & 0 & \\
\hline 11 & 湯吞白等 & 0 & 0 & D \\
\hline & その他要望 & & & \\
\hline
\end{tabular}

表 4 2013年＼cjkstart品種別ブレンド比率（\%)

\begin{tabular}{c|r|r|r|c}
\hline \multirow{2}{*}{ 供試品種 } & \multicolumn{3}{|c|}{ グループ番号 } & 品種別 \\
\cline { 2 - 4 } & 1 & 2 & 3 & 平均 \\
\hline やぶきた & 40 & 0 & 10 & 16.7 \\
さやまかおり & 20 & 30 & 30 & 26.7 \\
ふくみどり & 20 & 10 & 50 & 26.7 \\
ほくめい & 0 & 20 & 10 & 10.0 \\
ゆめわかば & 20 & 40 & 0 & 20.0 \\
\hline
\end{tabular}

\section{表 5 2013年 品種の特徵別ブレンド比率（\%)}

\begin{tabular}{c|c|c|c|c|c}
\hline \multirow{2}{*}{ 嘹好属性 } & \multicolumn{3}{|c|}{ グループ番号 } & 赀好該当 & \multirow{2}{*}{ 全平均 } \\
\cline { 2 - 4 } & 1 & 2 & 3 & 平均 & \\
\hline さっぱり味 & 60 & 30 & 40 & 60.0 & 43.3 \\
\hline こく味 & 40 & 70 & 60 & 56.7 & 56.7 \\
\hline 苦渋味 & 20 & 30 & 30 & 25.0 & 26.7 \\
\hline 強い香気 & 20 & 60 & 10 & 35.0 & 30.0 \\
\hline 甘い香気 & 20 & 40 & 0 & 20.0 & 20.0 \\
\hline
\end{tabular}

注) 1 「表 2 供試品種の特徴とブレンドに際する考え方」における, 嗜 好属性に該当する品種のブレンド比率の合計。

注) 2 墸好該当平均は，嗜好調查の嗜好属性該当項目にチェックを入れた グループのブレンド比率 (口) 合計／チェックを入れたグループ数。

注) 3 全平均は, 全グループの喏好属性に該当する品種のブレンド比率 合計 /グループ数
味においては,「さっぱり味」を嗜好したグループの ブレンド全体に占める「さっぱり味」の嗜好属性を持 つ品種のブレンド割合は $60.0 \%$ で, グループ全体の平均 43.3\%に比ベブレンド比率は高くなった。「こく味」を嗜 好したグループのブレンド全体に占める「こく味」の嗜 好属性を持つ品種のブレンド割合は $56.7 \%$ で, グループ 全体の平均 $56.7 \%$ と同じになった。「苦渋味」を喏好した グループのブレンド全体に占める「苦渋味」の嗜好属性 を持つ品種のブレンド割合は $25.0 \%$ で, グループ全体の 平均 $26.7 \%$ に比べ少なくなった。

香気においては,「強い香気」を嗜好したグループの ブレンド全体に占める「強い香気」の嗜好属性を持つ品 種のブレンド割合の合計は $35.0 \%$ で, グループ全体の平 均 $30.0 \%$ よ高くなった。「甘い香気」を嗜好したグルー プのブレンド全体に占める「甘い香気」の嗜好属性を持 つ品種のブレンド割合は $20.0 \%$ で, グループ全体の平均 20.0\%と同じになった。

\section{1. 2 2014年}

問診票による嗜好調査の結果, 味は「さっぱり味」を 希望が 4 組, 「こく味」を希望が 4 組, 「苦渋味」の希望 が 3 組, 香気は「強い香気」の希望が 3 組, 「甘い香気」 が 6 組, 水色が「緑色」希望が 5 組などとなった (表 6 )。 最終的に, 2014年の参加グループ 9 組（グループ番号 1９）が最も好ましいとした品種比率と, グループ全 体の品種別の平均比率について示した（表 7 )。

次に, 各嗜好属性に応じたブレンド結果を示す (表 8 )。 なお, グループ番号 7 については浄水器を使用以外に はすべての項目に該当との回答があり, またグループ番 号 8,9 については老人施設入居者のグループのため, 嗜好調査に基づいたブレンドとは言えない可能性がある ため, グループ番号 1 〜 6 を正式データーとし, グルー

表 6 2014年 問診票による嗜好調査結果

\begin{tabular}{|c|c|c|c|c|c|c|c|c|c|c|}
\hline \multirow{2}{*}{\multicolumn{2}{|c|}{ 問診項目 }} & \multicolumn{9}{|c|}{ グループ番号 } \\
\hline & & 1 & 2 & 3 & 4 & 5 & 6 & 7 & 8 & 9 \\
\hline 1 & さっぱり味 & 0 & 0 & 0 & & & & 0 & \multirow{11}{*}{\multicolumn{2}{|c|}{$\begin{array}{l}\text { 老人施設入居者のため、 } \\
\text { 口頭聞き取りのみ }\end{array}$}} \\
\hline 2 & こく味 & 0 & & & 0 & 0 & & 0 & & \\
\hline 3 & 苦渋味 & & & 0 & 0 & & & 0 & & \\
\hline 4 & 味こだわり無 & & & & & & & 0 & & \\
\hline 5 & 強い香気 & & & 0 & 0 & & & 0 & & \\
\hline 6 & 甘心香気 & 0 & 0 & 0 & 0 & & 0 & 0 & & \\
\hline 7 & 香気こだり無 & & & & & & & 0 & & \\
\hline 8 & 水色緑 & 0 & & & 0 & 0 & 0 & 0 & & \\
\hline 9 & 水色こだう無 & & 0 & 0 & & & & 0 & & \\
\hline 10 & 浄水器等使用 & 0 & & 0 & 0 & & & & & \\
\hline 11 & 湯吞白等 & 0 & & & 0 & & & 0 & & \\
\hline 12 & その他要望 & & & & & 甘味少 & 苦味少 & $\begin{array}{l}\text { 今までにな } \\
\text { いタイプ }\end{array}$ & 普通の & な香味 \\
\hline
\end{tabular}


表 7 2014年＼cjkstart品種別ブレンド比率（\%)

\begin{tabular}{|c|c|c|c|c|c|c|c|c|c|c|}
\hline \multirow{2}{*}{ 供試品種 } & \multicolumn{9}{|c|}{ グループ番号 } & \multirow{2}{*}{$\begin{array}{c}\text { 品種別 } \\
\text { 平均 }\end{array}$} \\
\hline & 1 & 2 & 3 & 4 & 5 & 6 & 7 & 8 & 9 & \\
\hline やぶきた & 50 & 50 & 40 & 30 & 20 & 20 & 0 & 30 & 80 & 35.6 \\
\hline さやまかおり & 0 & 20 & 10 & 20 & 0 & 40 & 10 & 10 & 0 & 12.2 \\
\hline ふくみどり & 0 & 10 & 20 & 20 & 40 & 40 & 10 & 60 & 10 & 23.3 \\
\hline ほくめい & 20 & 20 & 20 & 10 & 20 & 0 & 10 & 0 & 0 & 11.1 \\
\hline ゆめわかば & 30 & 0 & 10 & 20 & 20 & 0 & 70 & 0 & 10 & 17.8 \\
\hline
\end{tabular}

表 8 2014年＼cjkstart品種の特徵別ブレンド比率（\%)

\begin{tabular}{|c|c|c|c|c|c|c|c|c|c|c|c|}
\hline \multirow{2}{*}{ 嗜好属性 } & \multicolumn{9}{|c|}{ グループ番号 } & \multirow{2}{*}{$\begin{array}{c}\text { 嗜好該当 } \\
\text { 平均 }\end{array}$} & \multirow{2}{*}{ 全平均 } \\
\hline & 1 & 2 & 3 & 4 & 5 & 6 & 7 & 8 & 9 & & \\
\hline さっぱり味 & 50 & 70 & 50 & 50 & 20 & 60 & 10 & 40 & 80 & 56.7 & 50.0 \\
\hline こく味 & 50 & 30 & 50 & 50 & 80 & 40 & 90 & 60 & 20 & 60.0 & 50.0 \\
\hline 苦渋味 & 0 & 20 & 10 & 20 & 0 & 40 & 10 & 10 & 0 & 15.0 & 15.0 \\
\hline 強い香気 & 50 & 20 & 30 & 30 & 40 & 0 & 80 & 0 & 10 & 30.0 & 28.3 \\
\hline 甘い香気 & 30 & 0 & 10 & 20 & 20 & 0 & 70 & 0 & 10 & 12.0 & 13.3 \\
\hline
\end{tabular}

注）１「表２＼cjkstart供試品種の特徵とブレンドに際する考え方」における，嗜好属性に該当する品種のブレンド比率の合計。

注) 2 グループ番号 $7 \sim 9$ は，問診票の項目に基づくブレンドではないので参考值とし，平均值にはカウントしない。

注) 3 嗜好該当平均は，嗜好調查の嗜好属性該当項目にチェックを入れたグループのブレンド比率（【）合計／チェックを入れたグループ数。

注) 4 全平均は, グループ番号 1 ～6 の嗜好属性に該当する品種のブレンド比率合計 $/$ グループ数（グループ番号 $1 \sim 6)$ 。

プ番号 7 〜 9ブレンド比率などは参考データーとした。 味においては,「さっぱり味」を嗜好したグループの ブレンド全体に占める「さっぱり味」の嗜好属性を持 つ品種のブレンド割合は $56.7 \%$ で, グループ全体の平均 $50.0 \%$ に比ベブレンド比率は高くなった。「こく味」を嗜 好したグループのブレンド全体に占める「こく味」の嗜 好属性を持つ品種のブレンド割合は $60.0 \%$ で, グループ 全体の平均 $50.0 \%$ に比べ高くなった。「苦渋味」を嗜好し たグループのブレンド全体に占める「苦渋味」の嗜好属 性を持つ品種のブレンド割合は $15.0 \%$ で，グループ全体 の平均 $15.0 \%$ と同じになった。

香気においては，「強い香気」を嗜好したグループの ブレンド全体に占める「強い香気」の嗜好属性を持つ 品種のブレンド割合は $30.0 \%$ で, グループ全体の平均
28.3\%に比べ高くなった。「甘い香気」を嗜好したグルー プのブレンド全体に占める「甘い香気」の嗜好属性を 持つ品種のブレンド割合 $12.0 \%$ で, グループ全体の平均 $13.3 \%$ に比べ低くなった。

\section{1 . 32016 年}

問診票による嗜好調査の結果，味は「さっぱり味」を 希望が 4 組, 「こく味」を希望が 8 組, 「苦渋味」を希望 が 3 組, 香気は「強い香気」の希望が 6 組,「甘い香気」 が 7 組, 水色が「緑色」希望が 5 組などとなった (表 9$)$ 。 最終的に，2016年の参加グループ12組（グループ番号 1１2）が最も好ましいとした品種比率と, グループ全 体の品種別の平均比率について示した（表10）。

次に，各嗜好属性に応じたブレンド結果を示す（表 $11)$ 。

表 9 2016年 問診票による嗜好調査結果

\begin{tabular}{|c|c|c|c|c|c|c|c|c|c|c|c|c|c|}
\hline & \multirow{2}{*}{ 問診項目 } & \multicolumn{12}{|c|}{ グループ番号 } \\
\hline & & 1 & 2 & 3 & 4 & 5 & 6 & 7 & 8 & 9 & 10 & 11 & 12 \\
\hline 1 & さっぱり味 & O & & & $\bigcirc$ & & & $\bigcirc$ & & O & & & \\
\hline 2 & こく味 & & 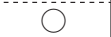 & & & ○ & 0 & & & & & & ) \\
\hline 3 & 苦渋味 & & & & & & & & 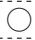 & & & ) & 0 \\
\hline 4 & 味こだわり無 & & & & & & & & & & & & \\
\hline 5 & 強い香気 & 0 & 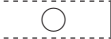 & & & & & & 0 & & 0 & 5 & 5 \\
\hline 6 & 甘い香気 & & 0 & 0 & 5 & 0 & 0 & & & 0 & 0 & & \\
\hline 7 & 香気こだわり無 & & & & & & & & & & & & \\
\hline 8 & 水色緑 & & & & & 0 & & $0^{-}$ & 0 & & D & & \\
\hline 9 & 水色こだわり無 & & 5 & & 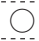 & & 0 & & & 0 & & & \\
\hline 10 & 浄水器等使用 & & & & & & & & & & & & \\
\hline 11 & 湯吞白等 & 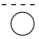 & $\mathrm{O}^{-}$ & O & & $\mathrm{O}$ & $\mathrm{O}$ & & & & & & O- \\
\hline & その他要望 & & $\begin{array}{l}\text { 甘み・旨 } \\
\text { 味・こく }\end{array}$ & & & $\begin{array}{l}\text { 苦渋 } \\
\text { 味少 }\end{array}$ & 甘み & & & $\begin{array}{l}\text { 苦味 } \\
\text { 嫌い }\end{array}$ & & & \\
\hline
\end{tabular}


表10２016年＼cjkstart品種別ブレンド比率（\%）

\begin{tabular}{|c|c|c|c|c|c|c|c|c|c|c|c|c|c|}
\hline \multirow{2}{*}{ 供試品種 } & \multicolumn{12}{|c|}{ グループ番号 } & \multirow{2}{*}{$\begin{array}{c}\text { 品種別 } \\
\text { 平均 }\end{array}$} \\
\hline & 1 & 2 & 3 & 4 & 5 & 6 & 7 & 8 & 9 & 10 & 11 & 12 & \\
\hline やぶきた & 14 & 32 & 29 & 43 & 20 & 16 & 34 & 0 & 20 & 20 & 25 & 17 & 22.5 \\
\hline さやまかおり & 14 & 16 & 14 & 0 & 0 & 34 & 33 & 25 & 40 & 0 & 25 & 17 & 15.3 \\
\hline むさしかおり & 14 & 0 & 14 & 14 & 40 & 34 & 0 & 25 & 20 & 0 & 25 & 16 & 16.8 \\
\hline ほくめい & 29 & 0 & 28 & 29 & 0 & 0 & 33 & 25 & 0 & 40 & 25 & 16 & 21.6 \\
\hline おくはるか & 29 & 52 & 15 & 14 & 40 & 16 & 0 & 25 & 20 & 40 & 0 & 34 & 23.8 \\
\hline
\end{tabular}

表11２016年＼cjkstart品種の特徵別ブレンド比率（\%）

\begin{tabular}{|c|c|c|c|c|c|c|c|c|c|c|c|c|c|c|}
\hline \multirow{2}{*}{ 嗜好属性 } & \multicolumn{12}{|c|}{ グループ番号 } & \multirow{2}{*}{$\begin{array}{c}\text { 嗜好該当者 } \\
\text { 平均 }\end{array}$} & \multirow{2}{*}{ 全平均 } \\
\hline & 1 & 2 & 3 & 4 & 5 & 6 & 7 & 8 & 9 & 10 & 11 & 12 & & \\
\hline さっぱり味 & 42 & 48 & 57 & 57 & 60 & 84 & 67 & 50 & 80 & 20 & 75 & 50 & 61.5 & 57.5 \\
\hline こく味 & 58 & 52 & 43 & 43 & 40 & 16 & 33 & 50 & 20 & 80 & 25 & 50 & 43.6 & 42.5 \\
\hline 苦渋味 & 14 & 16 & 14 & 0 & 0 & 34 & 33 & 25 & 40 & 0 & 25 & 17 & 22.3 & 18.2 \\
\hline 強い香気 & 72 & 52 & 57 & 57 & 80 & 50 & 33 & 75 & 40 & 80 & 50 & 66 & 65.8 & 59.3 \\
\hline 甘い香気 & 43 & 52 & 29 & 28 & 80 & 50 & 0 & 50 & 40 & 40 & 25 & 50 & 45.6 & 40.6 \\
\hline
\end{tabular}

注）1「表 2 供試品種の特徵とブレンドに際する考え方」における，嗜好属性に該当する品種のブレンド比率の合計。

注) 2 嗜好該当平均は, 嗜好調査の嗜好属性該当項目にチェックを入れたグループのブレンド比率（ロ）合計／チェックを入れたグループ数。

注) 3 全平均は，全グループの嗜好属性に該当する品種のブレンド比率合計／グループ数。

味においては,「さっぱり味」を喏好したグループの ブレンド全体に占める「さっぱり味」の喏好属性を持 つ品種のブレンド割合は $61.5 \%$ で, グループ全体の平均 $57.5 \% に$ 比べ高くなった。「こく味」を嗜好したグループ のブレンド全体に占める「こく味」の嗜好属性を持つ品 種のブレンド割合は $43.6 \%$ で，グループ全体の平均 $42.5 \%$ に比べ高くなった。「苦渋味」を嗜好したグループのブ レンド全体に占める「苦渋味」の嗜好属性を持つ品種の ブレンド割合は $22.3 \%$ で, グループ全体の平均 $18.2 \% に$ 比べ高くなった。

香気に㧍いては，「強い香気」を嗜好したグループの ブレンド全体に占める「強い香気」の嗜好属性を持つ 品種のブレンド割合は $65.8 \%$ で, グループ全体の平均 59.3\%に比べ高くなった。「甘い香気」を嗜好したグルー
プのブレンド全体に占める「甘い香気」の嗜好属性を持 つ品種のブレンド割合は $45.6 \%$ で，グループ全体の平均 40.6\%に比べ高くなった。

\section{1.42017 年}

問診票による喏好調査の結果，味は「さっぱり味」を 希望が 5 組,「こく味」を希望が11組，「苦渋味」を希望 が 5 組，香気は「強い香気」の希望が 8 組，「甘い香気」 が 8 組, 水色が「緑色」希望が 8 組などとなった（表 12)。

最終的に，2017年の参加グループ14組（グループ番号 1１4）が最も好ましいとした品種比率と，グループ全 体の品種別の平均比率について示した（表13）。

次に，各嗜好属性に応じたブレンド結果を示す（表 14)。

表12 2017年 問診票による嗜好調査結果

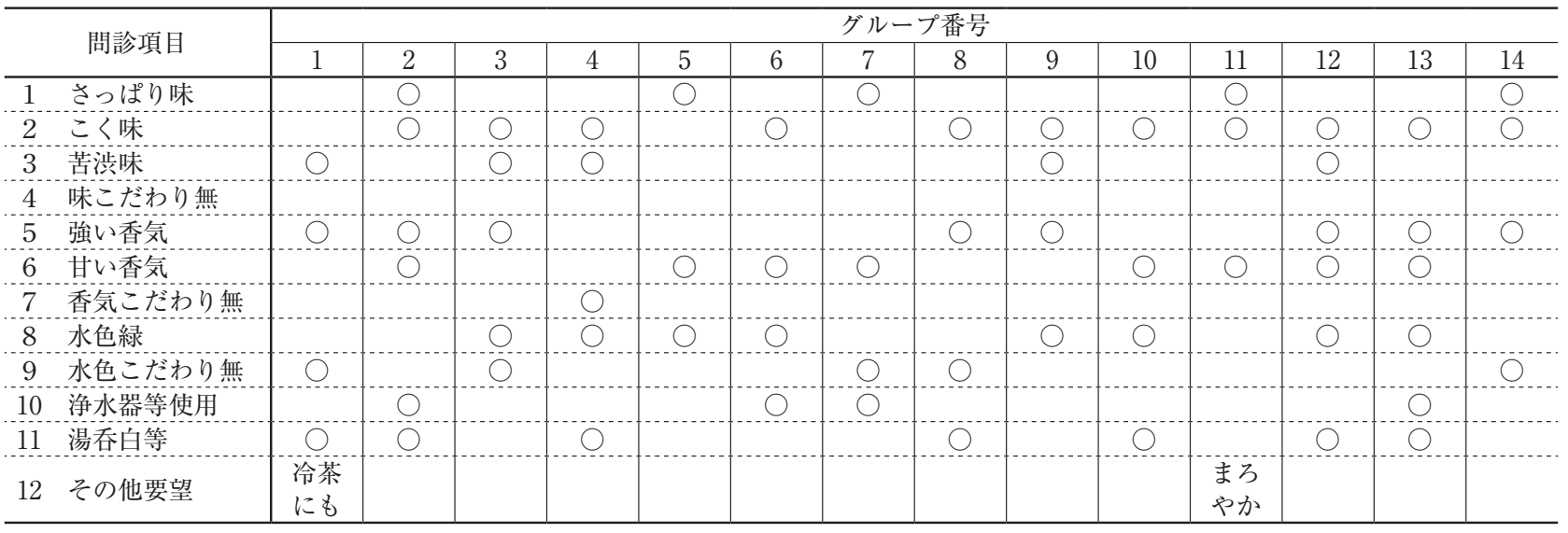


表13２017年＼cjkstart品種別ブレンド比率（\%)

\begin{tabular}{|c|c|c|c|c|c|c|c|c|c|c|c|c|c|c|c|}
\hline \multirow{2}{*}{ 供試品種 } & \multicolumn{14}{|c|}{ グループ番号 } & \multirow{2}{*}{\begin{tabular}{|c} 
品種別 \\
平均
\end{tabular}} \\
\hline & 1 & 2 & 3 & 4 & 5 & 6 & 7 & 8 & 9 & 10 & 11 & 12 & 13 & 14 & \\
\hline やぶきた & 0 & 34 & 70 & 0 & 50 & 70 & 50 & 50 & 0 & 20 & 0 & 20 & 20 & 25 & 29.2 \\
\hline さやまか抢り & 50 & 0 & 0 & 0 & 0 & 30 & 25 & 0 & 34 & 0 & 0 & 50 & 0 & 0 & 13.5 \\
\hline ふくみどり & 25 & 0 & 0 & 50 & 20 & 0 & 0 & 0 & 33 & 40 & 50 & 0 & 40 & 25 & 20.2 \\
\hline ほくめい & 25 & 33 & 0 & 50 & 0 & 0 & 0 & 0 & 33 & 20 & 25 & 30 & 40 & 25 & 20.1 \\
\hline こまかげ & 0 & 33 & 30 & 0 & 30 & 0 & 25 & 50 & 0 & 20 & 25 & 0 & 0 & 25 & 17.0 \\
\hline
\end{tabular}

表14 2017年 品種の特徵別ブレンド比率（\%）

\begin{tabular}{|c|c|c|c|c|c|c|c|c|c|c|c|c|c|c|c|c|}
\hline \multirow{2}{*}{ 嗜好属性 } & \multicolumn{14}{|c|}{ グループ番号 } & \multirow{2}{*}{$\begin{array}{l}\text { 嗜好該 } \\
\text { 当平均 }\end{array}$} & \multirow{2}{*}{ 全平坽 } \\
\hline & 1 & 2 & 3 & 4 & 5 & 6 & 7 & 8 & 9 & 10 & 11 & 12 & 13 & 14 & & \\
\hline さっぱり味 & 50 & 67 & 100 & 0 & 80 & 100 & 100 & 100 & 34 & 40 & 25 & 70 & 20 & 50 & 64.4 & 59.7 \\
\hline こく味 & 50 & 33 & 0 & 100 & 20 & 0 & 0 & 0 & 66 & 60 & 75 & 30 & 80 & 50 & 44.9 & 40.3 \\
\hline 苦渋味 & 50 & 0 & 0 & 0 & 0 & 30 & 25 & 0 & 34 & 0 & 0 & 50 & 0 & 0 & 26.8 & 13.5 \\
\hline 強い香気 & 25 & 66 & 30 & 50 & 30 & 0 & 25 & 50 & 33 & 40 & 50 & 30 & 40 & 50 & 40.5 & 37.1 \\
\hline 甘い香気 & 0 & 33 & 30 & 0 & 30 & 0 & 25 & 50 & 0 & 20 & 25 & 0 & 0 & 25 & 16.6 & 17.0 \\
\hline
\end{tabular}

注）1「表 2 供試品種の特徵とブレンドに際する考え方」における，嗜好属性に該当する品種のブレンド比率の合計。

注) 2 嗜好該当平均は, 嗜好調查の嗜好属性該当項目にチェックを入れたグループのブレンド比率（ロ）合計/チェックを入れたグループ数。

注) 3 全平均は, 全グループの嗜好属性に該当する品種のブレンド比率合計／グループ数。

味においては,「さっぱり味」を嗜好したグループの ブレンド全体に占める「さっぱり味」の嗜好属性を持 つ品種のブレンド割合は $64.4 \%$ で, グループ全体の平均 59.7\%に比べ高くなった。「こく味」を嗜好したグループ のブレンド全体に占める「こく味」の嘹好属性を持つ品 種のブレンド割合は $44.9 \%$ で, グループ全体の平均 $40.3 \%$ に比べ高くなった。「苦渋味」を嗜好したグループのブ レンド全体に占める「苦渋味」の嗜好属性を持つ品種の ブレンド割合は $26.8 \%$ で，グループ全体の平均 $13.5 \%$ に 比べ高くなった。

香気においては,「強い香気」を嗜好したグループの ブレンド全体に占める「強い香気」の嗜好属性を持つ 品種のブレンド割合は $40.5 \%$ で, グループ全体の平均 $37.1 \%$ に比べ高くなった。「甘い香気」を嗜好したグルー プのブレンド全体に占める「甘い香気」の嗜好属性を持 つ品種のブレンド割合は $16.6 \%$ で, グループ全体の平均 $17.0 \%$ に比べ低くなった。

\section{2 銘茶会に対する感想の聴取}

すべてのアンケート回答者すべてからから，銘茶会は 「よかった」との回答を得た。特に, 品種のブレンドに よって香味が大きく変化することに強い印象を持ったと の回答が多くあった。

\section{4 考察}

\section{1 嗜好調査について}

農林水産省が実施した食料品消費者モニターの調査結 果では, 緑茶に求めるものとして「旨さ」を回答者の $79 \%$ が，「香り」は回答者の $71 \%$ が求めているのに対し, 水色（緑色）を求めている回答者は $18 \%{ }^{\dagger}$ となっている。 銘茶会における嗜好調查結果の記述，ブレンド選定のや り取りや試飲の感想からも, 煎茶に求める品質の優先順 位は, 味, 香気, 水色の順である可能性が高いと推測さ れた。しかしながら銘茶会での嗜好調査は, 品種のブレ ンドを選定することを目的に質問項目を設定したため， 質問項目の数に違いがあるなど, 品質の優先順位を完全 に決定するには更なる調查，検証が必要と考えられる。 また，後述するように嗜好調査に基づいた著者の考える 味や香気と, 参加者が求める味や香気には違いがあるこ とが明らかになり, 単なる味や香気などの品質の重みづ けでは消費者の嗜好に合致するブレンドを決定できない ことが分かった。

飲用のこだわりについてでは，銘茶会の参加者は茶の イベントの来場者であるので, 茶の飲用については一定 のこだわりがあると予想していた。しかし，浄水器など 飲用の水にこだわっているとの回答は半数にも満たなか った。茶は, 水の違いによって味や香気, 時には水色が

平成17年度食料品消費モニタ一第 2 回定期調查結果, p.7

http://www.maff.go.jp/j/heya/h_moniter/pdf/h1702.pdf 
大きく変化する。生産者が, 味や香気などにこだわって 茶を造っても, 水道水をそのまま使って茶を淹れては, 味や香気などの特徵は十分に生かせない。品種ばかりで はなく，水によっても茶の品質が変化することも説明す る必要を感じた。

また，湯吞についても白色以外のもの，すなわち水色 が分からない湯吞を使っている参加者が半数近かった。 このことも，消費者が水色についてはこだわりが少ない ことを示していると考えられる。

な㧍、参加者が複数人数グループではグループ内で意 見が一致せず，特定の参加者の嗜好が強く反映されてブ レンドしたケースもあった。その場合は, 参加者個々の 喏好の集約ではなく, 特定の参加者の嗜好によるブレン ドになった。そのため, 個々の嗜好に細かく対応した多 様なブレンド方法などについては，今後検討する必要が あると考えられる。

さらに，消費者に対する品種のアピールも兼ねたイベ ントのため, 品種紹介において埼玉県育成品種などを記 述したため, 特定の品種単品の希望やブレンド比率を上 げるような希望があった。しかし，それら特定の品種比 率を上げるなどのブレンドは, 最も嗜好のあったブレン ドとはらなかった。このことから，香味や産地などの特 徵のある品種であっても，消費者の嗜好に完全に合致す ることは難しく, 特定の品種単品よりも様々な品種のバ ランスの中で，狙いとする品種の特徵を生かしたブレン ドをする必要があると考える。

\section{2 ブレンド結果について}

\section{2. 1 味の嗜好について}

「さっぱり味」を嗜好するグループ数は少なかったが, さっぱり味を嗜好したグループのさっぱり味の嗜好属性 を持つ品種の最終ブレンド比率は 2 組のグループを除き 50\%以上になり, 参加グループ全体のさっぱり味のブレ ンド平均にくらべても高い傾向にあった。このことから さっぱりした味という嗜好については，参加者による感 受性の違いは少ないと推測され, 嗜好属性として利用で きる可能性があると考えられる。

「こく味」を啫好する回答は最も多数になった。こく 味を嗜好したグループの最終ブレンド平均では, こく味 の喏好属性を持つ品種のブレンド割合は全体量の $40 \%$ を 超えた。しかし，こく味を嗜好するグループの最終ブレ ンドに扔ける，こく味の嗜好属性を持つ品種と参加グル ープ全体の割合には大きな開きがあった。例えば, 2017 年のグループ番号 $2 \sim 4,6,8 \sim 14$ はいずれも，こく味
を希望するとの回答であったが, 最終ブレンドではグル ープ番号 4 がこく味の嗜好属性を持つ品種が $100 \%$ あ゙あ ったのに対し，グループ番号 $3,6,8$ はこく味の嗜好属 性を持つ品種が 0 \%になった。

この原因として二つの要因が推定される。一つは,さ っぱりした味とは異なり参加者と著者の感受性の違いが 大きいことである。もう一つの要因は, 著者のブレンド シミュレーションにおいて, さっぱり味や苦渋味に比べ てこく味を感じる䦨值が低いことである。例えば ‘やぶ きた’にこく味が強く感じられる ‘くくどり’ $10 \%$ と, 同じ ‘やぶきた’に苦渋味を強く感じる‘さやまか打り’ 10\%ブレンドした場合，“ふくみどり’をブレンドした 場合はこく味を強く感じるようになるが，“さやまか扔 り’をブレンドした場合は，苦渋味よりもわずかな味の 変化を感じるにすぎない。しかしながら，味の閾値は著 者の主観的な味覚によるものであり。嗜好調查と実際の ブレンドが異なる原因は, 試飲をした参加者の感想を詳 細に聞きだし検証していく必要があると考える。これら のことから，こく味は嗜好属性とするには更なる検証が 必要と考えられる。

「苦渋味」を嗜好したグループは全体の約 $34 \%$ あっ た。しかし, 事前のブレンドシミュレーションで著者が しっかりとした苦渋味を感じるとした，苦渋味の特徴を 持つ品種のブレンド比率が $50 \%$ 以上になったのは, 2107 年のグループ番号 $1 ， 12$ のみであった。逆に 2017 年のグ ループ番号 3,4 はブレンド比率が $0 \%$ であった。他の 年も抒むむ 10 ～ $30 \%$ のブレンド比率になり，苦渋味を 嗜好するとしても, 苦渋味は著者の想定よりも強く感じ る要素であると推定された。しかし, 口頭などで苦渋味 の少ない味を希望したグループの参加者に“さやまかお り’を除いたブレンドを提供したところ, 苦渋味が不足 するとの回答も少なからずあり, 苦渋味を欲しない場合 でも一定の苦渋味がアクセントとしては必要であること が分かった。

これらのことから苦渋味という嗜好属性については, 参加者による感受性の違いはやや大きいと推測され, 嗜 好属性としての利用には更なる検討が必要であると考え られる。

\section{2. 2 香気の嗜好について}

「強い香気」を嗜好したグループにおいて, 強い香気 の喏好属性を持つ品種の最終ブレンド比率は2013年と 2017 年の各 1 組のグループを除き $30 \%$ 以上になり, 参加 グループ全体の強い香気の嗜好属性を持つ品種のブレン ド平均に比べても高い傾向にあった。しかし，味と同様 
に最終ブレンドに占める香気に特徴のある品種比率には 大きなばらつきがあり, さらに特定の品種の香気ではな く, 複数品種の香気の組み合わせを好む傾向にあった。 これは，香気は味よりもさらに消費者の喏好性向があい まいになり，個々の品種ごとに持つ特徵ある香気や香気 そのものの強さ求めるだけではなく，味などと組み合わ せた総合的なバランスのうえに香気の嗜好があると考え る。また一方で, 銘茶会での浸出条件は, 深蒸し煎茶を 急須で淹れることを想定したため, $60^{\circ} \mathrm{C} \cdot 30$ 秒という浸 出条件も香気の特徵が十分に出なかったこともばらつき の一因であると考えられる。

これらのことから香気の強さという喏好属性について は，参加者によって感受性の違いはやや大きいと推測さ れるが，嗜好属性としての利用は可能であると考えられ る。ただし，香気の多様性は品種や製造工程による萎调 香など様々なものがあり，単なる香気の強弱だけではな く, 品種など香気の種類やその組み合わせと消費者の嗜 好についても検討する必要があると考える。

「甘い香気」を喏好したグループの割合は，強い香気 を喏好したグループよりも多かったが，最終ブレンド比 率はばらつきが大きく，甘い香気の嗜好属性を持つ品種 のブレンド比率が $30 \%$ 未満になったものも少なくなかっ た。また年によっては, 参加グループ全体の, 強い香気 の嗜好属性を持つ品種のブレンド平均にくらべて低くな る傾向にあった。このことは,「甘い香気」という属性 表現が曖昧であったことのほか，銘茶会で使用した甘い 香気を持つ品種は緑茶品種としては香気も強いため, 参 加者は少量のブレンドでも甘い香気を認識することがで きたと考えられる。また，2016年の ‘扔くはるか’ のよ うに甘い香気に加えてうま味もある品種は，嗜好性の高 いうま味により選択性が高くなるなどの原因と推測され る。

これらのことから，甘い香気という莻好属性について は，参加者によってイメージの違いが大きいほか，味の 嗜好属性により選択性が変化することも推定され, 嗜好 の属性として利用については更なる検討が必要であると 考えられる。

\section{2.3 水色の嗜好について}

呈茶後の口頭での感想の中に味や香気に関するものは 多くあったが，水色についての感想や希望はほとんどな かった。これは品種によっては水色に赤みがあるものも あったが，多くの供試品種が緑色ないし黄緑色で、それ らの品種との組み合わせによってほぼ問題のない水色に なったためと考えられる。また，水色に赤みがあっても
特徵のある強い香気を希望するケースもあり, 水色が香 気などの特徴に比べ優先度が低いことを示していると推 測された。

\section{2. 4 銘茶会に対する感想と今後の課題}

銘茶会は，消費者の嗜好という新たな属性を設定し， その嗜好属性を直接聞き出し, かつ嗜好属性を確認・共 有しながら個々の嗜好属性に合った品種のブレンドを行 うことでより細かく喍好の多様性に対応ができる。この ような考え方に基づいて実施した銘茶会について，銘茶 会の感想に対するアンケートを提出した参加者のすべて から，「よかった」との回答を得た。このことは，産地 表示や商品の特徴を文字情報などで提示し, 莻好の合否 は消費者の判断に任せるといった方法に比べ情報の非対 称性を小さくし，消費者の潜在的な不満を解消するのに 有効な手段であると考える。

また，本来の目的である参加者の喏好に合ったブレン ドができたこと以上に，品種や品種のブレンドで香味に 多様性が生まれることに強い印象をもっていた。このこ とは, 緑茶の品種やブレンドに関する情報は, 消費者に はまだほとんど認知されていないことや，茶業者の行う ブレンドの多くが，茶業者の嗜好に基づき製品の品質を 画一化させてロット数を減らす手段としてのブレンドと 異なると考える。

さらに銘茶会のブレンドのための喏好聴取に際し, 著 者が緑茶の品質に基づいて定義した嗜好属性と, 消費者 が理想とする嗜好属性の感受性が完全には合致しないこ とも分かってきた。紅茶では大野 ${ }^{6)}$ が, 紅茶キャラク ターホイールにより紅茶の特徵を客観的に共有する手法 を報告している。しかし緑茶では，前掲の對比地 ${ }^{4)}$ が テアニン単独の味覚についての表現を検証した報告はあ るが，香味などの特徵表現が客観性を持って消費者に伝 えられているかを検証した報告は見当たらない。緑茶に 扔ける品質などの特徴を, 茶業者と消費者が客観的に共 有できる手法が確立されるまでは，嗜好属性の確認には 単なる文字情報などの提示だけではなく，喍好を直接聞 き出し, かつ嗜好の属性を確認・共有する必要があると 考える。

その他，銘茶会に扔いて嗜好に合致するブレンドにな るまでのブレンド回数は, 記録に残っている範囲では平 均2.2回であった。また, 嗜好調查から最終ブレンドま での所要時間が1グループ平均15分程度かかった。銘茶 会のようなイベントの企画としての問題はないが，一般 の市販茶販売では所要時間がかかりすぎるため, 市販茶 に合った操作などを検討する必要がある。 


\section{5 摘 要}

消費者の嗜好の多様性に応じた品種ブレンドを明らか にするため, 埼玉県茶業研究所で行われた消費者向けイ ベントにおいて，「オーダー銘茶会」と称する企画を実 施した。オーダー銘茶会では, 消費者の味や香気などの 嗜好を嗜好属性として新たに位置づけ，5種類の緑茶用 品種を組み合わせてブレンドを実施した。その結果，品 種の組み合わせは参加者ごとに異なり，消費者の緑茶に 対する嗜好が多様であることが裏付けられた。また，嗜 好属性をもとにした品種の柔軟なブレンドは嗜好の多様 性に応えうる手段として有効であることが分かった。し かしながら，味や香気などの嗜好をブレンドのための所 属属性とした場合, 香味などの感受性は個人差があり, 香味などの品質の特徵を嗜好の属性として利用すること については更なる検討が必要であると考えられた。

\section{6 謝 辞}

2017年の銘茶会では，埼玉県茶業青年団の所沢・三芳
地区から品種茶の提供と補助員の御協力をいただいた。 また，埼玉県農業技術研究センターの小俣良介氏，株式 会社寺田製作所の澤村章二氏から貴重なご意見をいただ くことにより，銘茶会の記録を本報告としてとりまとめ ることができた。ここに記して，謝意を表します。

\section{7 引用文献}

1 ）糀谷 斉・合崎英男（2011）：産地ブランド確立に向けた緑茶 産地のマーケティング戦略. 農業経営研究, 49(1), 1-12.

2 ) 植松恵美子·勝野 剛・畑中義生·後藤 正・小林利彰 (2017) : 香り緑茶における品質表示の有効性に関する調査．茶研報， No.124（別)，69.

3 ）川口史樹 (2016)：日本茶イノベーション 茶品種から見るマ 一ケットと課題. 茶, 69(8), 42-44.

4 ）對比地信夫 (2015)：緑茶の味質に関する調査 -2 呈茶から 見た緑茶の喍好，茶研報，No.120（別)，62-63.

5 ）㴊之上康元・㴊之上弘子（1999）：日本茶全書. 農文協，p244.

6 ）大野敦子 (2014)：紅茶キャラクターホイールの作成と紅茶特 徵の可視化。に扮い・加り環境学会誌，45，344-350。 